\title{
The Dynamics of Political Parties' Coalition in Indonesia: The evaluation of political party elites' opinion
}

\author{
Ardian Maulana \\ ai@compsoc.bandungfe.net \\ Dept. Computational Sociology \\ Bandung Fe Institute
}

\author{
Deni Khanafiah \\ dk@compsoc.bandungfe.net \\ Dept. Evolutionary Economics \\ Bandung Fe Institute
}

\begin{abstract}
During the Indonesian president election process, the coalition of parties could be shown as the dominant process beside the president campaign. The coalition could be regarded as the emergence of the parties' preferential coherence based upon the interest and attributes of each party. The similarity and difference of parties' preference and attributes could be depicted through of party elites' opinions and attitude toward flowered political issues. In this paper, we use the Heider's balance theory to construct relation network among parties by using the longitudinal news data of the party elite's opinion that published by the media, and then analyze the dynamic of coalition formation in the Indonesian political system during the election process. We have shown that the balance of the party's relational network move toward the larger balance index relative to the initial condition. This phenomenon has verified the structural balance hypothesis especially for the conflict situation such as the election process. Interestingly, the balance of the system is fluctuated dynamically through time following certain trajectory. This dynamics is divided into 3 phases, that is, disorder state, conflict state, and order state, as well as signed the difference of party behavior before and after the legislative election. Moreover, we also analyzed the stability two parties' relation in particular period in order to understand specifically the dynamic of the system in triadic level.
\end{abstract}

Keywords: Coalition, party elites' opinion, relation network, Heider's balance theory, balance index, stability index 
"Nobody would choose to live without friends, even if he had all the other good things" Aristotle. (1955). The Ethics of Aristotle: The Nichomachean Ethics.

\section{Introduction}

In the presidential government with multiparty system like Indonesia, when the legislative election has resulted fragmentation political map without a single majority party, the coalition among parties is considered as the only way to achieve the majority position in parliament. In case of Indonesia, instead as a balancing power for the elected government, the majority position is more intended to support the president candidacy, since president candidate should be formally endorsed by one or more parties that collectively have one fourth legislative members. In the president election, the coalition is also used to mobilize voters and to decrease the uncertainty of voter behavior by gaining the advantage from parties' voters. Therefore, it is not surprising if the coalition process of parties could be shown as the dominant process beside the president campaign during the president election. The dynamics of coalition process is depicted from the party elites' opinion and the effort of each party to make political communication with other parties.

The coalition among party could be regarded as the emergence of the parties' preferential coherence based upon the interest and attributes of each party. In this context, the coalition process would be related with the evaluative efforts of the party's relation with other parties by concerning a lot of issues and interests, and then integrates them as the decision to which parties they will coalesce. This process becomes a complex thing, since the party should compromise a lot of its preference based upon their mainstreams or profiles. Hence, we can say that the dynamics of one party's preference to become a coalition partner of other parties, could be regarded as the effort to reconcile the tension that emerges because of preferences reevaluation that constrained by several party's attributes as well as their commitments to constituents.

From the Hederian perspective of social psychology, the tension or pressure in the actor's relations is related with psychologically uncomfortable feeling when actor found the imbalance situation in her interpersonal relations. Based upon Heider's balance theory, the imbalance condition will enforce the actor to reevaluate her preference and change their preference toward the balance state, which is psychologically more comfortable [5]. In social structure constituted by many actors, the dynamics of actors' preference is regarded as the driving force of the dynamics of relation network towards the balance condition. The balance condition will be emerged as clustered group where actors within particular group would share their similar attribute while in return they are strengthen their differences with the out-group actors.

The "social mitosis" is regarded as the balance condition [11]. Commonly, it strongly tends to occurs in conflicting situation (10) such as the coalition process of political parties. In the coalition process, the similarity of parties' characteristics and attributes become basic requirements to make a political communication among parties, which in turn will enforce the change in their preferences in order to increase the party relation coherence. In this case, coalition among parties will be emerged as the "mitosis" of relation network into two or more coalesced parties, where the parties within one coalition will have positive attitude toward each other, while they have a negative attitude toward the out-group parties. Davis [2] elaborated further the dynamical process of opinion change toward the convergence preference and group formation. He hypothesized that such kind dynamics commonly occurs in 3 stages: First, the innovation, this is the situation where particular $\mathrm{x}$ issue is introduced into the system. Second, the preferential change, this is the situation where actors within the system change or strengthen her previous preference because of the present of the $\mathrm{x}$ issue. Third, the conflict stage, this is the situation where the actors within the system will have different preferences, whether positive or negative preference toward the $x$ issue.

During the Indonesian election process, it has been shown how opinion and polemics among parties related with a lot of political issues become a dominant topic in mass media. This phenomenon is bolstered during legislative election and reached the peak toward the deadline time of president and vice president candidacy for president election. We have assumed that party elites' opinions are representing the parties' preference, opinions and polemics among political parties. These opinions have also depicted a similarity and a difference of parties' 
attitude toward flowered political issues. Moreover, we understood this phenomenon as the coalition sounding process before the "real" political communication is performed by the political parties. In this situation, the mass media is role as the mediator that clarifies the parties' preference signal headed for several political issues. Mass media clarification will reduce the information asymmetric among parties during sounding process as well as to reaffirm the position and relation among parties related with several public political issues.

In this paper, we use the Heider's balance theory for many agents to analyze the Indonesian political system empirically. Here, we present the party elites' opinions concerning a lot of issues during the election process as the relation network among parties. The dynamics of this relation network is expected to estimate or infer a clear picture of coalition configuration process of the Indonesian political parties and then analyze further to gain deeper understanding about the basic political process in Indonesian political system. We used the party elites' opinions that we collect from Indonesian electronic mass media, i.e. Detik.com ${ }^{1}$ form January to May 2009. These opinions we modeled as relation network, and then we analyze the dynamics of relation network structure during particular period, as well as the dynamics of this relation network to the balance state. We also propose the coalition stability variable as hypothetically relation that aggregated from the parties' preferences toward the coalition issues.

\section{The Construction of Relation Network}

Basic concept of Heider's balance theory is simply described in pox triad relation (figure 1), where $p$ and $o$ are actors (exp: party elites) or personal entities representation, and $x$ is impersonal entity such as situation, phenomenon or object. The relation in this triad model could be categorized into two types relation namely unit formation relation $(o \rightarrow x$ and $p \rightarrow x$ ) and affected relation $(p \rightarrow o)$. The former is the relation which shows the similarity of $p$ toward $x$, causality of $p$ toward $x$, the membership of $p$ toward $x$, while the latter is the relation which shows an attitude (love or hate, like or dislike) of $p$ toward $o$ as the consequence of $p \rightarrow x$ and $o \rightarrow x$ relation [5]. In further development, when the cognitive representation among actors in form of pox triad is used to analyze the system with many actors, pox triad is simply replaced with poq, where $p-o$ relation is considered as consequence of $p$ and $o$ relation toward $\mathrm{q}$ (or another personal entity). In the poq representation, the unit formation relation is neglected. By this kind of representation, the system with many actors is easier to be modeled as system with many poq triads. However, according to Doreian [3], this simplification makes the balance theory is less of meaning. Doreian has shown that balance theory will be meaningful empirically only if those two types of relation is considered in data mining as well as data representation and analysis.

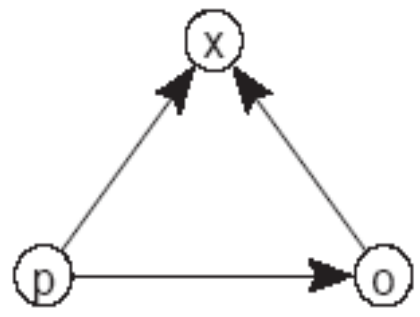

Figure 1

Heider pox model (Heider, 1946). pox triad where $p$ and $x$ are actor and o is object

In this paper, we depicted the dynamics of relation balance between political parties and issues involved in this relation during the coalition process of parties in 2009 election. These relation is represented as undirected graph $A(N, E)$ where $n$ is parties and issues $\left(n_{i} \in N\right)$ and $e$ is signed relation among nodes $\left(e_{i j} \in E\right)$, where positive preference is signed as 1 and negative preference is signed as -1 . According to a formed relation, we could extract information about the balance condition of entire triadic relation in the network based upon the balance principle

${ }^{1}$ http://www.detik.com 
of triadic relation, that is, as the multiplication of the relation value of the triadic. In this way, balance state will occur when there are sentiment relations with signs all positive $(+x+x+=+)$, or two negatives and one positive ($x-x+=+$ ). Moreover, we also consider the all-negative relation as balanced to accommodate the possibility of group breaking into more than two mutually hostile sub groups [2].

In our relation network of parties and issues, in order to evaluate the balance value of the network, we should determine the parties' relation as well as its value of its relation toward other parties or issues. In this paper, we assume that the certain party's preference is represent by the aggregation of its members' opinion. The members' opinion is chosen as the representation of party's preference since we cannot recognize the parties' preference directly before the party convention is performed. In case of Indonesia, a lot of parties commonly conduct their convention when the limit time of candidacy has approached. Therefore, in the coalition configuration process, the dynamics of parties' preference could be inferred or estimated through the dynamics of parties' member opinions. Here, we do not take into account the quality of issues and opinion of the parties' member since we assume that media own certain mechanism to determine which opinion and issues are published to public. It means that published opinion is considered as the opinion of capable party's member. The aggregation of party member's preference into a party's preference is performed by the equation as follow:

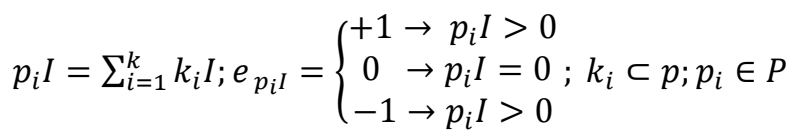

where $I$ is the node of issue, $p_{i} I$ is the aggregation of party-issues relation, $k_{i} I$ is the relation of party's members toward $I$ issue, and $e_{p_{i} I}$ is the signed value of the party-issue relation.

However, the complexity of semantic of the data news make the problem of subjective inference could be unavoidable in this work. Moreover, the nature of political elite behavior in Indonesia causes the effort to infer the value of relation should do carefully. As example, we should treat positive and negative opinion differently because of it have different implication in Indonesian political system.

The node of issue that involved in construction of the unit formation relation of party-issue as well as the affected relation of party-party is divided into 3 types as follow:

- Candidacy Issue $\left(I_{\text {cand }}\right)$ : this issue is related with the candidacy of certain person that will be participate in the president election (exp: Susilo Bambang Yudoyono (SBY) as the candidate of president, Jusuf Kala as the candidate of president, Jusuf Kala as the candidate of vice president with SBY as the president, etc). Here, we assume that inherently the nodes that represent the president or vice president candidacy issue will have a negative relation each other. Therefore, the opinion which showing the support to certain candidacy issue $\left(I_{\text {cand }}\right)$ in certain time $(t)$ can discharge the previous time $(t-1)$ support to another candidacy issue. It means that one party's member cannot have positive preference to several candidacy issues in the different $t$ time, except for negative relation or support in the same time (figure 2). However, this condition is not applicable for the party level, because certain party could have the positive relation to several candidates, when its members are maintained different supported candidates. The positive relation of party to only one candidacy issue could be conducted after it has decided its support by the party's national convention.

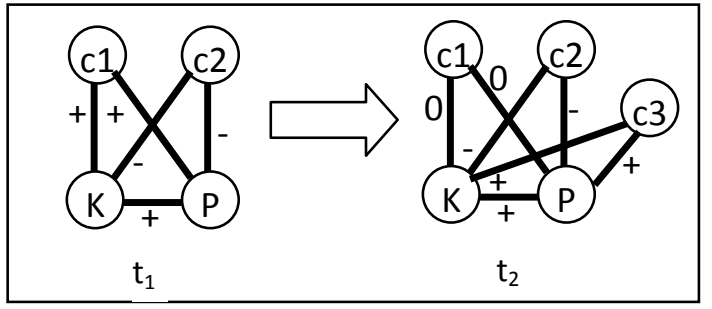

Figure 2

The dynamics of triad relaton of party-issue 
- Non- candidacy issue ( $\left.I_{\text {noncand }}\right)$ : This is the issue which is not related with the candidacy, such as the government direct assist program, election delay issue, critic to the government, etc. These issues are different with the candidacy issue since the relation among these issues is assumed to be independent. Therefore, the party's member preference to the certain issue in certain time will not influence her preference to other issues in the next time.

- Coalition issue ( $\left.I_{\text {coalition }}\right)$. This is the issue which related to the coalition among parties (exp: coalition among PDIP and Gerinda, etc). Similar with non-candidacy issue, the coalition issue is also assumed to be independent each other, since coalition could be conducted by two or more parties. It means that the party's member could make opinion in certain time which supports different coalition issues without nullify previous opinion. Differ from two other issues above, the coalition issue is functioned to conduct the affected relation among parties who support or not support certain coalition issue. Hence, the aggregation of party-issue preference in the party-party-issue triad is performed as follow:

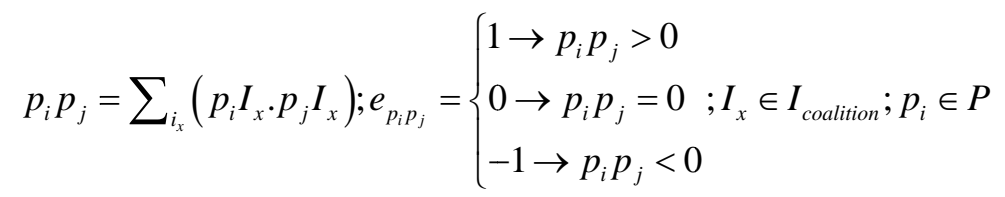

where $\mathrm{p}_{\mathrm{i}} \mathrm{p}_{\mathrm{j}}$ is the aggregation of party-party relation, $\mathrm{p}_{\mathrm{i}} \mathrm{l}_{\mathrm{x}}$ is the certain party-coalition issue relation, and $\mathrm{e}_{\mathrm{pipj}}$ is the signed value of party-party relation. The aggregation of relation value according to the equation above is not performed once the relation of two party nodes toward the coalition issue has a negative value. Similar with the candidacy issue, when the two parties officially announce they coalition, their preference to other coalition issue and their affected relation with other parties in the previous time is discharged. However, in the next time, party could assemble the coalition with other parties without breaking its previous coalition.

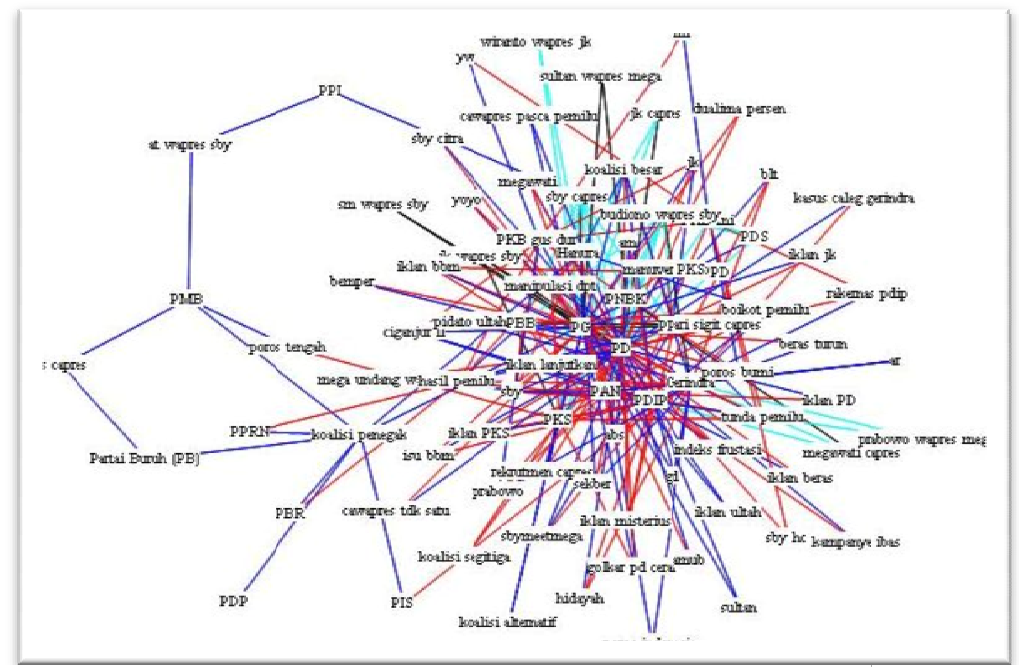

Figure 3

Relation network among parties and issue which constructed using the party elites' opinion from January $6^{\text {th }}$ through May $15^{\text {th }}$ 2009. (Blue $=$ positive preference, red $=$ negative preference, cyan $=$ coalition $/$ official endorsement, black $=$ competition)

\section{The Dynamics of Political Elites Relation}

Relation balance perspective in structural level is constructed by hypothesized that relation network among actors will go toward the balance state along with a time. The dynamics of system toward the balance state is measured by using the global balance index [7] as follow: 
$\beta_{\text {global }}=\frac{\sum_{j \leq I} T_{\text {balance }}}{\sum_{I} T_{\text {total }}}$

Where $T_{\text {balance }}$ is the number of balance triad and $T_{\text {total }}$ is the number of triad in the system.

In this paper, we used party elites' opinion data that published by Detik.com from January $6^{\text {th }}$ through May $15^{\text {th }}$ 2009 in order to construct the relation network among political parties. As the initial condition, we have assumed that the relation among political parties have followed the coalition pattern of 2004 legislative election, which is divided as two coalition group, i.e., the supporting government parties (PD, PG, PBB, PKB mi, PAN and PPP) and the opposition parties (PDIP). With the model as we have explained above, we have observed the dynamics of preferential change till the new coalition was formed. Figure 3 depicts the relation network among parties in the 2009 election toward several issues appeared during the observation time. In general, the parties are clustered into three coalition groups, i.e. PD - PPP-PKB mi-PAN- PBB coalition, PG - Hanura coalition, and PDIP - Gerindra coalition.

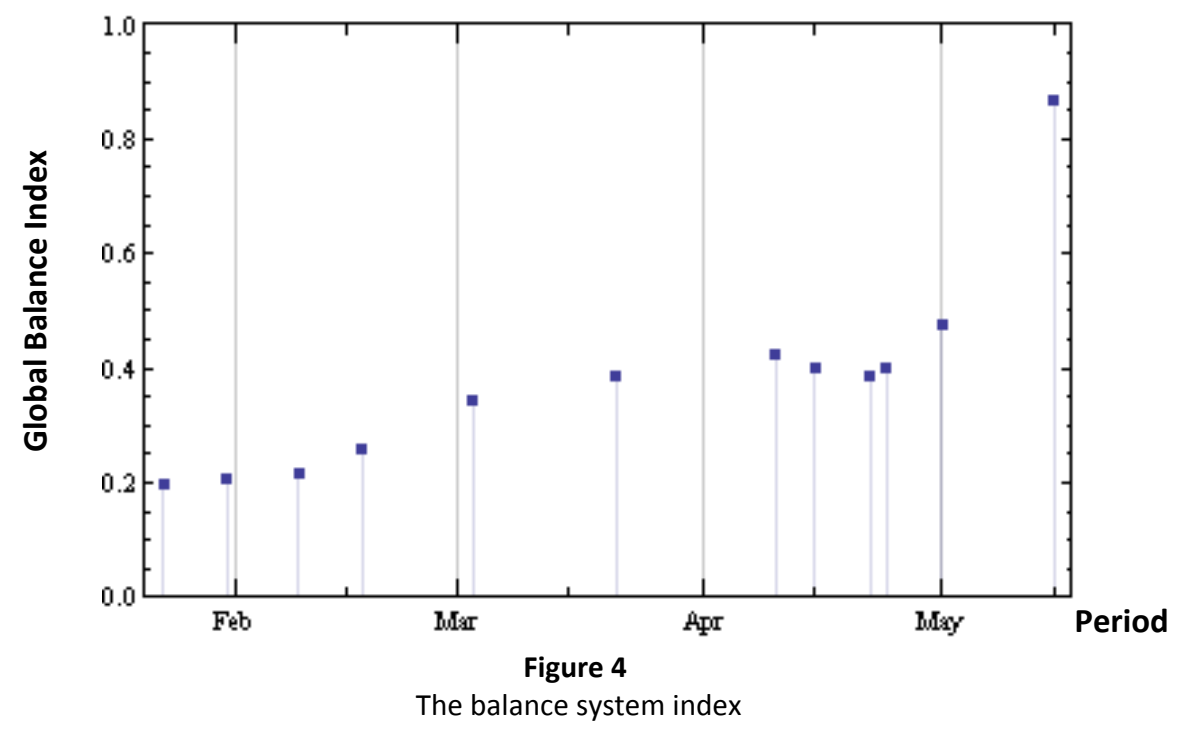

The dynamics of relation network is examined based upon the change of its global balance index. Figure 4 illustrates the global balance index graphic per 50 news period (over 617 in total). From this figure we could recognize that the balance index value of system is increasing throuh time relative to the initial value. In general, this pattern is verified the basic hypothesis of structural balance theory that the system will tend to move toward the balance condition. The alteration of balance index of macro-level system is the consequence of the actor's effort to increase the coherence of her relation while at once decreasing the "psychological tension" because of imbalance condition of her interpersonal relationship at micro-level. However, from this figure we can also see that between April and May period, the balance index value is tend to decline till certain point and then raise again. This pattern shows that "the system tends to move toward the balance condition hypothesis" is no more than the generalization of entire system dynamics. The balance index of system could fluctuate at certain time interval while overall it tends to increase. This phenomenon has also shown in the previous work $[6,8]$. Furthermore, the figure 4 has shown that the balance value of the system is less than 1 at the end of observation period. This condition has indicated that the construction of party coalition is not followed by the mitosis of relation network. In order to see how mitosis is not occurred, we should examine the dynamics of parties' relation at triad level.

Generally speaking, the party's coalition is based upon two basic principles, i.e. the similarity of political party's attributes (party's platform, its preference toward issue, party's characters, etc), and the agreement about the candidate to be endorsed for the president election. In this paper, both principles are represented by candidacy and non-candidacy issue aspect. The stability of two parties' relation related with these aspects $\left(S I_{i j}\right)$ at certain 
period could be examined by calculating the number of balance triads relative to total triad that constructed by this relation, as follow:

$S I_{\text {total }}^{i, j}=\alpha S I_{I_{\text {cand }}}^{i, j}+(1-\alpha) S I_{I_{\text {noncand }}}^{i, j} ; \alpha+(1-\alpha)=1$

$S I_{I_{\text {noncand }}^{i, j}}=\frac{\sum_{R_{i . j} \leq I_{\text {noncand }}^{i, j}} T_{\text {balance }}}{\sum_{I_{\text {noncand }}^{i, j}} T_{\text {total }}}$

$S I_{I_{\text {cand }}}^{i, j}=\frac{1}{2}\left(\frac{\sum_{R_{i . j} \leq I_{c}^{i, j} T_{\text {balance }}}}{\sum_{I_{c}^{i, j}} T_{\text {total }}}+\frac{\sum_{R_{i, j} \leq I_{w}^{i, j}} T_{\text {balance }}}{\sum_{I_{w}^{i, j}} T_{\text {total }}}\right)$

Where $\alpha$ is the influence level of candidacy and non-candidacy issue to the party's relation stability. Since we don't know exactly the influence level of each issue, we have used $\alpha=0.5$. The dynamics of party's relation at triadic level for $\alpha=0.5$ is depicted in figure 5 and 6 .
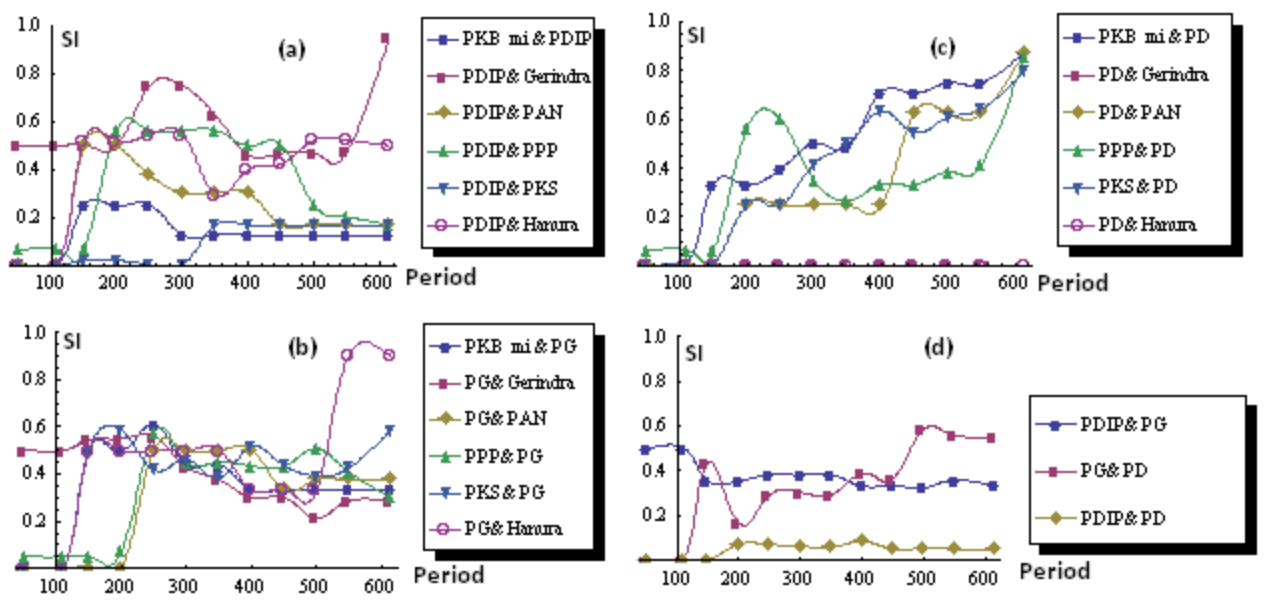

Figure 5

The dynamics of relation stability of PDIP, PG and PG toward several parties, i.e. (a). PDIP, (b). PG, (c). PD, (d). PDIP, PG and PD

In figure 5 we can see that there is the incoherence of parties' preference from same coalition clusters as well as from different coalition clusters. From this figure, we could also identify that at triadic level the parties that coalesced into different coalition have maintained its similarity toward certain issues. This situation has made the relation network among parties is still imbalance at the end of observation period, even tough, at macro level the relation network was divided into three official coalition cluster. Moreover, this relation incoherence is related with parties' preference toward the non-candidacy issues (figure 6a-6d). In general, we could articulate that the party elites infrequently reevaluate their preference toward the non-candidacy issues than candidacy issues. This phenomenon has indicated how the political parties need to maintain their voter by not altering their preference toward certain issue that is related with their party's mainstreams or profiles. The assumption of independence among issues has also made less of tension that enforcing the political parties to change their attitude toward noncandidacy issues. The opposite phenomenon is occurred at party's triad relation to candidacy issue. Figure 6a-6d has shown how party's preference to candidacy issue is coherent with the configuration of coalition. We can see 
how the party's preference toward candidacy issue is change dynamically through time. This observable fact is possibly related with the strong influence of candidacy issue for the negotiation process and bargaining position of parties to other parties. The parties tend to re-evaluate their opinion toward candidacy issue when the negotiation process among to build the coalition was deadlock.
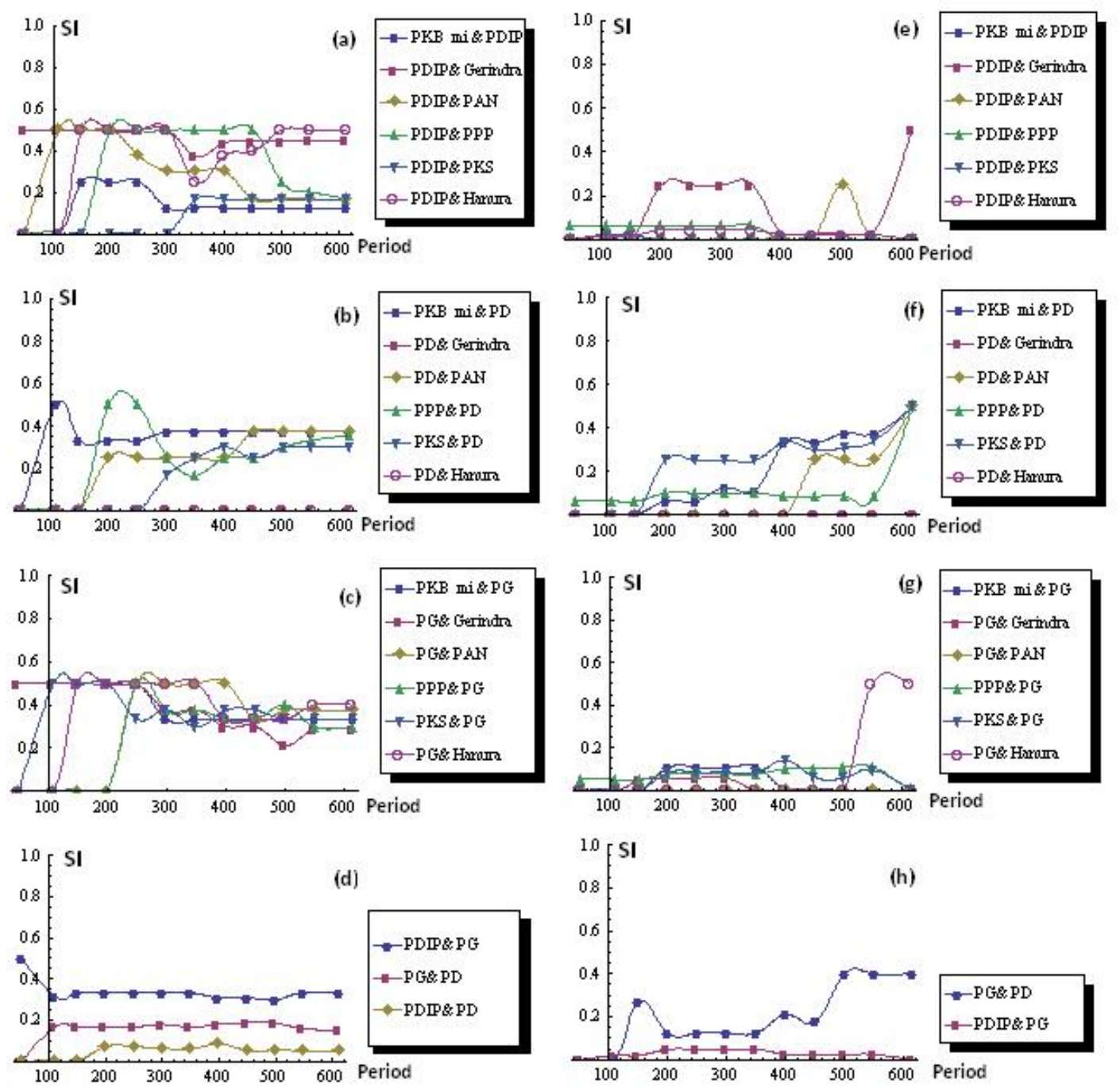

Figure 6

The dynamics of relation stability of PDIP, PG and PG to other parties regarding noncandidacy issues $(\boldsymbol{a}, \boldsymbol{b}, \boldsymbol{c}, \boldsymbol{d})$ and candidacy issues $(\boldsymbol{e}, \boldsymbol{f}, \boldsymbol{g}, \boldsymbol{h})$.

From figure 6, the dynamics of party's relation could be partition into two periods, i.e. the period before legislative election (periods $<350$ ) and after legislative election (periods $>350$ ). In periods before legislative election, the balance of party's relation - that assumed is followed the 2004 coalition configuration, is disturbed by the occurrence of several issue regarding the government performance, party elites' polemic, coalition initiation by several parties and the emergence of alternative candidates (see appendix I). The diversity of parties' preference toward the emerged issues has made the balance index of this period was very low. However, the diversity of issue could emerge the rivalry among several parties. Generally, the political dynamics during the election is dominated by the a lot of preference differences between PDIP and PD. Rivalry among both parties that regarded the noncandidacy issue as well as the candidate to be projected in 2009 election was very stable during the election 
(figure $6 \mathrm{~d}$ and $6 \mathrm{~h}$ ). This rivalry - which is occurred because of the difference positioning and mainstreams- was enforced the system toward the balance state. Another interesting party is PG. Before 2009 election PD and PG has coalesced into one coalition that was supports the government with PDIP as opposition party. However, during the 2009 election the stability index of PG and PD relation is relatively low than the stability among PG and PDIP (figure 5d). This has been shown the strong tendency from PG party to emerge as the new alternative coalition bloc beside PDIP and PD rivalry.

The dynamics of relation among these three parties is expected has made the fragmentation among parties. However, it is not suddenly enforcing the convergence of parties' relation into new coalition. Figure 6a-6c has depicted how the relation stability among the middle party such as PKB, PAN, PPP and PKS with PG, PDIP and PD relatively equal toward non-candidacy issues. In other words, in this period, those parties are not formally established their position and tend to open the communication possibility with all possible coalition. Moreover, this preference dissimilarity has made the progress of the system toward the balance state is relatively slow. From the figure $-6 \mathrm{~h}$ we could see that the balance index of parties' relation to candidacy issues is lower than noncandidacy issues. It is indicated that in this period, each party has not yet established which candidate will be supported. In other words, in pre-legislative period, the non-candidacy issue is more taking into account to make the political communication for coalition construction.

In the post-legislative election period, the tension to create the coalition is increasing. Especially when there is no party has been the majority, while in other side, according to the election system, the candidate should be supported by almost one fourth parliament seats in order to be participated in the president election. In this period, the party elites' opinion related to candidacy issue and coalition became a dominant discourse (see Appendix I). The legislative election has placed PD, PG and PDIP as a three majority parties. This result has made the coalition formation is more influent by those parties. This situation also becomes the constraint for other parties such as PAN, PPP, PKS, PKB, PBB, Gerindra and Hanura to re-evaluate their preference toward the candidacy issues. As shown in figure 6e-6h, the stability index of party's relation related with candidacy issues is increasing in this period. Several middle parties where at initial time was coalesced with PG or PDIP turn their support for PD and making the political communication with it. At macro level, this dynamics has made the balance index of the system was decreasing. The system becomes critical and the complexity of the system is very high where one alteration of party's preference becomes more sensitive to influence the alteration of other party's preferences.

The trajectory to balance state in 2009 coalition was performed when PKB established it coalition with PD (at 350450 time period), and followed by the breaking process of PG with PD. PG itself is confidently announced their president candidate for 2009 election (at 450 time period). The balance index of the system drastically increased at the point when the coalition among PD with PKS, PAN and PBB was conducted, as soon as the formation of PDIP and Gerindra coalition.

\section{The Dynamics of Coalition Process}

By representing the dynamics of Indonesian political party's coalition as the dynamics of the balance index of the system, we could obtain the generalization of coalition process as illustrated in figure 7 . The trajectory of the system as shown in this figure is represented the dynamics of the system from disorder state, i.e. system with a lower balance, to order state, i.e. the coalition is formed and the system has reached an optimum balance. Interestingly, in the middle of its trajectory to the optimum balance state, the balance index of the system is unexpectedly having a trend to decline. This pattern is regarded as the system transition phase before it attains the optimum balance state. We could also consider it as the adaptation phase of the system toward the change of its environment, i.e. the post legislative election where the candidacy issue is emerged. At the micro-level of the change in the source of tension, i.e. the change in the object or issue that constructed the affected relation will make the change of parties' preference. The diversity of parties' preference at this phase is very high. This is the conflict situation where the parties have a tendency to maintain their self-preferences and interests. This condition has made the complexity level of system is reached a maximum level where the tension and dependence among actors is very high. Each party tends to wait the change of other party's preference, and then would rapidly reply those changes. Small change in the party's preference would determine the configuration state of party's relation in the end of period. 
The dynamics of the parties' relation periods in the coalition building (figure 7), is related with the change in the basic mechanism which drive the system toward the balance condition. As we mention before, we apparently see the change of the source tension that enforce the coalition formation among parties, i.e. the similarity of noncandidacy issue for the pre legislative election and then become the election result aspect and the similarity of candidate preference during the post legislative election. Doreian has explained the co-evolution process between actors' relation and social attributes, where the dynamics of system toward the balance condition is not only enforced by the triadic imbalance among actors (affected relation) but also by the triadic imbalance of actor toward their social attributes (unit formation relation) [3]. This could be occurred by the emergence of new social attributes or by the change of quality actor's unit formation relation toward existing social attributes. In other words, the emergence of new tension sources [10] will drive actors to change her preference and enforce the system toward the balance condition.

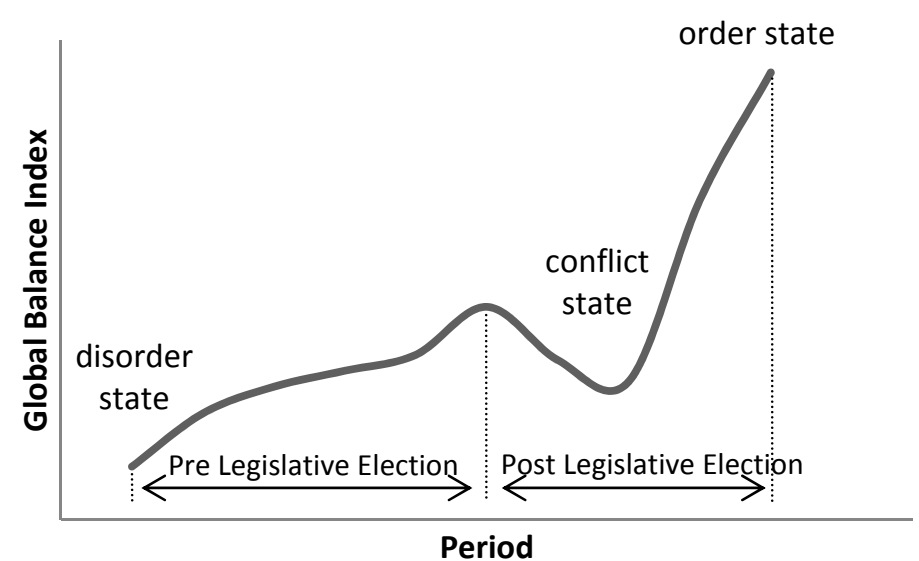

Figure 7

The dynamics of the system balance index periods

\section{Concluding remarks}

In this paper, we have shown how Heider's balance principle has developed in order to understand the coalition process of the Indonesian political parties. It is conducted by gathering the party elites' opinions toward many political issues that emerge during the election and then aggregated as the party's preference. According to Heiderian perspective, the dynamics of relation among parties is representing the effort of the parties to reconcile the tension because of triadic relation imbalance of parties relatively toward many political attributes that construct the relations. The coalition construction process only could be comprehensively examined using this approach if the social attributes aspect of actors and party's unit formation relation could be represented as the relation network. We have conducted the construction of this kind relation network by using the longitudinal news data of the party elites' opinion that published by the media during the election, and we have analyzed the dynamics of party's relation of the network during the coalition configuration.

We have analyzed the relation balance index and have shown that the balance of the political system move toward the larger balance index relative to the initial condition. It has been shown that dynamically the system tends toward the balance states through time during the coalition process. This phenomenon has verified the structural balance hypothesis, which stated the system tends toward the balance condition, especially for the conflict situation such as the election process. This occurs because of the presence of the tension from parties' imbalance "interpersonal" relation. This tension enforces the parties to increase their preferential coherences.

The change of parties' preference is the way for the parties to adapt with this tension. This preferential change has made the balance of the system is fluctuated dynamically through time following certain trajectory. This dynamics is divided into 3 phases, that is, disorder state, conflict state, and order state. The conflict state is the significant state, where the complexity level of the system is the highest, and the system is more sensitive to the change of 
the parties' preference where the small change will change the trajectory of the system and its final coalition configuration.

\section{Acknowledgment}

This research is performed as Dept. of Computational Sociology research framework. The authors would like to give sincere thanks to the researchers in BFI, for their support and discussions, and especially Syahfitri Anita for his aid during the translation process of the paper. The authors also thank Surya Research Int'l. for funding the research. All faults remain to authors.

\section{References}

[1] Cartwright, D.C., and Harary, F. (1956). "Structural balance: A generalization of Heider's Theory". Psychological Review, 63: 277-292.

[2] Davis,J. (1963). "Structural Balance, Mechanical Solidarity, and Interpersonal Relation". The American Journal of Sociology, 68(4): 444-462

[3] Doreian, P. (2004). "Evolution of Human Signed Networks". Metodolo `ski zvezki, 1(2): $277-293$

[4] Gallagher, et.al. (2005). Representative Government in Modern Europe 4th ed. McGraw-Hill. Boston.

[5] Heider, F. (1946). “Attitudes and cognitive organization”. Journal of Psychology. 45 : 107-112.

[6] Hummon, N.P. and Doreian, P. (2003). "Dynamics of Social Balance Processes". Social Networks, 25: 1749.

[7] Khanafiah, D. Situngkir, H. (2004). "Social Balance Theory, Revisiting Heider's Balance Theory for Many Agents". Working Paper Series. Bandung Fe Institute

[8] Maulana, A. (2008). "Dinamika Sentimen Pemilih dalam Simulasi Voting berbasis Agen”. Working Paper Series. Bandung Fe Institute

[9] Martin, L.W. and Vanberg,G. (): Coalition Government and Political Communication

[10] Mazur,A.,(1973), “Increased Tendency Toward Balance During Stressful Conflict”, Sociometry, 36(2): 279283

[11] Wang, Zhigang., Thorngate, Warrant. (2003). "Sentiment and Social Mitosis: Implications of Heider's Balance Theory". Journal of Artificial Societies and Social Simulation 6(3). URL: http//www.jasss.soc.surrey.ac.uk/6/3/2.html 
Appendix I: Tabel of issue that emergence during the election process.

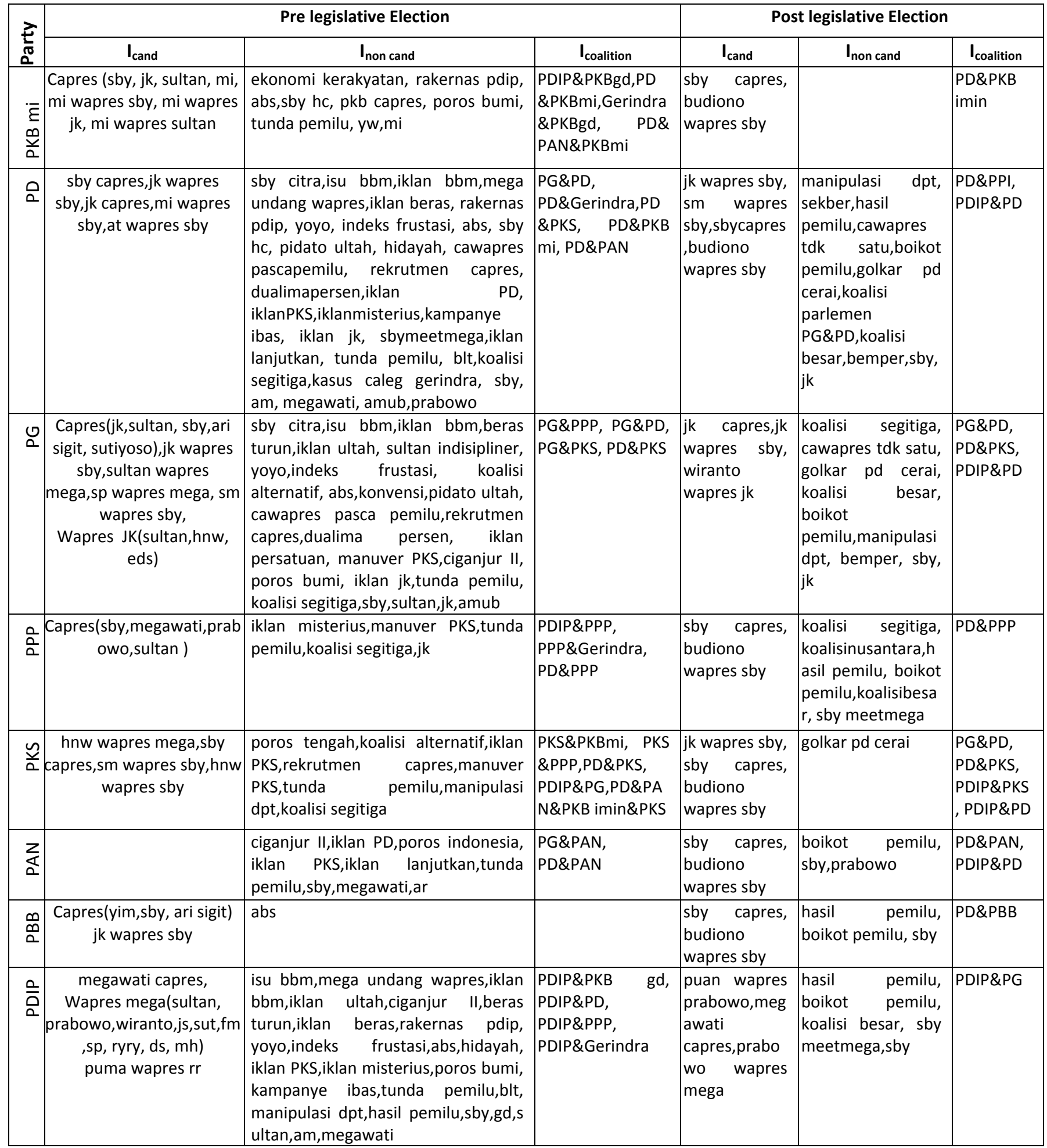




\begin{tabular}{|c|c|c|c|c|c|c|}
\hline 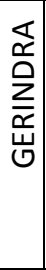 & $\begin{array}{c}\text { Capres(prabowo,megawat } \\
\text { i), prabowo wapres } \\
\text { mega,Wapres prabowo } \\
\text { (puma,ja,ds,yw,hnw,ts,mi, } \\
\text { ej,mdi,sp wapres } \\
\text { prabowo,su,fm,yc,at,sulta } \\
\text { n,sda,mh,ct }\end{array}$ & $\begin{array}{l}\text { abs, poros indonesia,pidato ultah, } \\
\text { hidayah, partai nasionalis,tunda } \\
\text { pemilu, manipulasi dpt, blt,kasus } \\
\text { caleg gerindra, hasil pemilu, } \\
\text { sby,gd,ar,prabowo }\end{array}$ & $\begin{array}{l}\text { PD\&Gerindra, } \\
\text { Gerindra\&PKB gd } \\
\text {,PDIP \& Gerindra, } \\
\text { PPP\&Gerindra,Ge } \\
\text { rindra\&PKS, } \\
\text { Gerindra \&PAN }\end{array}$ & $\begin{array}{l}\text { prabowo } \\
\text { wapres jk, } \\
\text { budionowapr } \\
\text { essby,megaw } \\
\text { aticapres,pra } \\
\text { bowowapres } \\
\text { mega }\end{array}$ & $\begin{array}{l}\text { hasil pemilu, } \\
\text { sekber,sbybertang } \\
\text { gungjawab, boikot } \\
\text { pemilu, koalisi } \\
\text { besar, } \\
\text { sby,prabowo }\end{array}$ & $\begin{array}{l}\text { PDIP\&Ger } \\
\text { indra, } \\
\text { Gerindra } \\
\text { \&PAN, } \\
\text { PDIP\&PD }\end{array}$ \\
\hline 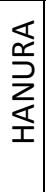 & $\begin{array}{l}\text { wiranto capres, wiranto } \\
\text { wapres mega }\end{array}$ & abs,koalisi penegak,manipulasi dpt & & \begin{tabular}{|l|} 
wiranto \\
wapres jk,jk \\
capres
\end{tabular} & $\begin{array}{l}\text { hasil pemilu, } \\
\text { sekber,boikot } \\
\text { pemilu,koalisi } \\
\text { besar,manipulasi } \\
\text { dpt,sby }\end{array}$ & $\begin{array}{l}\text { PG\&Hanu } \\
\text { ra }\end{array}$ \\
\hline
\end{tabular}




\begin{tabular}{|c|c|}
\hline \multicolumn{2}{|c|}{ Appendiks II } \\
\hline PKB mi & : Partai Kebangkitan Bangsa versi muhaimin iskandar \\
\hline PDIP & : Partai Demokrasi Indonesia Perjuangan \\
\hline PPP & : Partai Persatuan Pembangunan \\
\hline PKS & : Partai Keadilan Sejahtera \\
\hline PG & : Partai Golkar \\
\hline PNBK & : Partai Nasional Banteng Kemerdekaan \\
\hline PPI & : Partai Pemuda Indonesia \\
\hline PKB gus dur & : Partai Kebangkitan Bangsa versi Gus dur \\
\hline PMB & : Partai Matahari Bangsa \\
\hline PD & : Partai Demokrat \\
\hline PK & : Partai kedaulatan \\
\hline PPD & : Partai Persatuan Daerah \\
\hline PB & : Partai Buruh \\
\hline PM & : Partai Merdeka \\
\hline Gerindra & : Partai Gerakan Indonesia Raya \\
\hline PBB & : Partai Bulan Bintang \\
\hline Hanura & : Partai Hati Nurani Rakyat \\
\hline PAN & : Partai Amanat Nasional \\
\hline PIS & : Partai \\
\hline PPRN & : Partai Peduli Rakyat Nasional \\
\hline PDP & : Partai Demokrasi Pembaharuan \\
\hline PKNU & : Partai Kebangkitan Nahdatul Umat \\
\hline PBR & : Partai Bintang Reformasi \\
\hline PDS & : Partai Damai Sejahtera \\
\hline PR & : Partai Republikan \\
\hline PDK & : Partai Demokrasi Kebangsaan \\
\hline
\end{tabular}

